\title{
Characterization of adherens junction protein expression and localization in pituitary cell networks
}

\author{
Norbert Chauvet ${ }^{1,2,3,4}$, Taoufik El-Yandouzi ${ }^{1,2,3,4}$, Marie-Noëlle Mathieu ${ }^{1,2,3,4}$, \\ Audrey Schlernitzauer ${ }^{1,2,3,4}$, Evelyne Galibert ${ }^{1,2,3,4}$, Chrystel Lafont ${ }^{1,2,3,4}$, Paul Le Tissier ${ }^{5}$, \\ lain C Robinson ${ }^{5}$, Patrice Mollard ${ }^{1,2,3,4}$ and Nathalie Coutry ${ }^{1,2,3,4}$ \\ ${ }^{1}$ Département d'Endocrinologie, Institut de Génomique Fonctionnelle, 141 Rue de la Cardonille, 34094 Montpellier Cedex 05, France \\ ${ }^{2}$ Institut National de la Santé et de la Recherche Médicale (INSERM), Unité 661, Montpellier 34094, France \\ ${ }^{3}$ Centre National de la Recherche Scientifique (CNRS), Unité Mixte de Recherche (UMR) 5203, Montpellier 34094, France \\ ${ }^{4}$ Universités Montpellier I and II, Montpellier 34094, France \\ ${ }^{5}$ Division of Molecular Neuroendocrinology, National Institute of Medical Research, The Ridgeway, Mill Hill, London NW7 1AA, UK \\ (Correspondence should be addressed to N Coutry; Email: nathalie.coutry@igf.cnrs.fr; N Chauvet; Email: norbert.chauvet@igf.cnrs.fr)
}

\begin{abstract}
Our view of anterior pituitary organization has been altered with the recognition that folliculo-stellate (FS) and somatotroph cell populations form large-scale three-dimensional homotypic networks. This morphological cellular organization may optimize communication within the pituitary gland promoting coordinated pulsatile secretion adapted to physiological needs. The aim of this study was to identify the molecules involved in the formation and potential functional organization and/or signaling within these cell-cell networks. Here, we have focused on one class of cell adhesion molecules, the cadherins, since $\beta$-catenin has been detected in the GH cell network. We have characterized, by qPCR and immunohistochemistry, their cellular expression and distribution. We have also examined whether their expression could be modulated during pituitary tissue remodeling. The mouse anterior pituitary has a restricted and
\end{abstract}

cell-type specific repertoire of cadherin expression: cadherin11 is exclusively expressed in TSH cells; N-cadherin displays a ubiquitous expression pattern but with different levels of expression between endocrine cell types; E-cadherin is restricted to homotypic contacts between FS cells; while cadherin-18 is expressed both in somatotrophs and FS cells. Thus, each cell type presents a defined combinatorial expression of different subsets of cadherins. This cell-type specific cadherin expression profile emerges early during development and undergoes major changes during postnatal development. These results suggest the existence within the anterior pituitary of cell-cell contact signaling based on a defined pattern of cadherin expression, which may play a crucial role in cellular recognition during the formation and fate of pituitary cell homotypic networks.

Journal of Endocrinology (2009) 202, 375-387

\section{Introduction}

The anterior pituitary is a complex endocrine gland that transfers information between the brain and peripheral tissues, playing a pivotal role in the regulation of physiological functions such as reproduction, metabolism, and growth. The pituitary harbors several types of endocrine cells that release their hormone pulses into the systemic blood circulation, with intermingled supportive folliculo-stellate (FS) cells. For many years, two-dimensional histological studies on pituitary sections showed a heterogeneously scattered distribution of endocrine cells throughout the parenchyma, although specific topographic affinities between heterotypical and homotypical hormone-producing cells have been reported (Allaerts et al. 1991, Noda et al. 2001, Denef 2008). Pituitary cellular organization is now known to be much more ordered than was traditionally recognized. Cells are not randomly distributed throughout the gland, but are highly organized in homotypic three-dimensional network structures. For example, the non-endocrine FS cells and GH-secreting $(\mathrm{GH})$ cells (the major population of endocrine cells) have been shown to form intermingled populations of homotypically connected cells (Fauquier et al. 2001, Bonnefont et al. 2005).

The FS cells are connected by gap junctions, and form a dense three-dimensional cellular network pervading the entire gland (Soji et al. 1997, Fauquier et al. 2001). This network appears in rodent anterior pituitary 10 days after birth along the marginal cell layer, and is fully developed by day 40 (Soji et al. 1997). This FS cell network provides a functional circuitry allowing long-distance rapid intraorgan communication that could potentially regulate and coordinate distant endocrine cell activities (Fauquier et al. 2001, 2002). 
Similarly, three-dimensional analysis of the pituitary gland showed that GH cells form highly ordered strands and clusters of cells in homotypic contact throughout the organ, developing shortly after GH expression becomes apparent at embryonic day 16. Furthermore, the GH network organization is highly plastic and undergoes profound remodeling correlated with activity in the $\mathrm{GH}$ axis, in particular during puberty (Bonnefont et al. 2005).

The presence of these organized homotypic networks could provide the basis for coordinating the activities of different members of the same endocrine cell population within the pituitary gland, to generate efficient 'gland-wide' episodic secretory responses to neuroendocrine signals from the hypothalamus. However, the mechanisms by which pituitary cells develop functional homotypic connections are far from clear. Different contact and signaling mechanisms in the pituitary include gap junctions, adherens junctions, integrin, and cadherin complexes (Soji et al. 1997, Guerineau et al. 1998, Ezzat \& Asa 2005, Paez-Pereda et al. 2005). In addition to gap junctions, physical contacts between FS cells are mediated by adherens junctions (Soji et al. 1997), and we have shown that adherens junctions between GH cells actually resist physical dissociation, revealing the strong homotypic robustness of the GH cell network (Bonnefont et al. 2005).

Catenin/cadherin complexes are the transmembrane components of the adherens junction, and are therefore strong candidates for mediating both structural and signaling contacts between different pituitary cell types. Many members of the cadherin family are expressed in the developing vertebrate brain, where they play multiple roles during neuromorphogenesis (Redies et al. 2003, Suzuki \& Takeichi 2008), and their expression marks specific neural circuits (Suzuki et al. 1997). In endocrine tissues, cadherin roles are less well characterized, although E-cadherin regulates the adhesive properties of pancreatic $\beta$-cells, essential for their aggregation into islets (Dahl et al. 1996), and has been proposed to be involved in cellular proliferation and regulation of insulin secretion (Bosco et al. 2007, Carvell et al. 2007).

In the pituitary, E- and N-cadherins are known to be expressed in both normal and pathological tissues (Ezzat \& Asa 2005, Kikuchi et al. 2006, 2007), and Rubinek et al. (2003) reported that pituitary cell-cell contact mediated by $\mathrm{N}$-cadherin regulates $\mathrm{GH}$ secretion in vitro. Furthermore, when anterior pituitary cells are dissociated and cultured in suspension, they aggregate and form clusters after several days (Van der Schueren et al. 1982, Denef et al. 1989, Noda et al. 2003); cell adhesion molecules are likely to be key components in this reaggregation process. Since the pituitary is constituted of several different cellular types and its relative composition is highly plastic, we reasoned that there could be specific patterns of expression of cadherins that mediate and sustain the identities of contacting cells in their networks, with the potential of also contributing to functional signaling within the gland.
To begin to identify such molecular components, we analyzed both the expression and distribution of classic cadherins within the gland, and in purified cell populations. We have focused our studies during embryonic development, the postnatal period and between 15 and 150 days of life, periods that cover both the development of the established networks of FS and GH cells and the plasticity and profound remodeling of the gland that occur during sexual maturation.

\section{Materials and Methods}

\section{Animals}

Experiments were performed on C57BL/6J mice, either wild-type or hemizygous for a GH-eGFP transgene, driving GFP expression specifically in somatotrophs (Magoulas et al. 2000). In some experiments, GHRH-M2 mice, in which M2 viral channel is targeted in GHRH neurons, were used (Le Tissier et al. 2005). Animals were fed a normal diet and had free access to tap water. All animal studies complied with the animal welfare guidelines of the European Community. They were approved by the Languedoc Roussillon Institutional Animal Care and Use Committee (\#CE-LR-0818).

\section{Isolation of GH-secreting cells by FACS analysis}

Pituitary glands were dissected from 15 to 150-days-old male GH-eGFP mice $(n=10-30)$ and the neurohypophysis and intermediate lobe were removed. Glands were cut into small pieces in DMEM-F12 media, and then incubated at $37^{\circ} \mathrm{C}$ for 25 min with trypsin (0.5\%). After two successive incubations in HBSS $+2 \mathrm{mM}$ EDTA $\left(5 \mathrm{~min}\right.$ at $\left.37^{\circ} \mathrm{C}\right)$ and then in HBSS $+1 \mathrm{mM}$ EDTA $\left(15 \mathrm{~min}\right.$ at $\left.37^{\circ} \mathrm{C}\right)$, cells were mechanically dissociated with repeated gentle trituration using Pasteur pipettes. GH positive $(\mathrm{GH}+)$ cells were isolated from the other cell types (GH negative, GH-) by FACS (FACS Aria, BD Biosciences, Le Pont de Claix, France). Three independent experiments were performed at each age studied. The percentages of GH+ cells in the total cell population, measured during FACS analysis for the different groups of animals were: $27 \cdot 7 \pm 2 \cdot 33 \%$ for 15 -days-old mice; $36.7 \pm 1.64 \%$ at 30 days; $41.9 \pm 0.5 \%$ at 70 days; and $39 \cdot 4 \pm 1 \cdot 74 \%$ at 150 days. The number of GH cells purified from mature animals are in good agreement with previous studies (Sasaki \& Iwama 1988, Gubkina et al. 2001).

\section{Real-time quantitative PCR}

Total RNA was extracted from GH+ and GH - cells (or whole glands) and treated with DNase I using the RNA easy extraction kit (Qiagen). RNA (300 ng) was reverse transcribed using Superscript III reverse transcriptase (Invitrogen) and $250 \mathrm{ng}$ of random hexamer (Amersham Biosciences Europe) in a final volume of $20 \mu \mathrm{l}$. Real-time PCR analyzes of the classic cadherin family genes and Hprt, used as internal 
standard, were performed by SYBR Green PCR master mix (Applied Biosystems, Foster City, CA, USA) with 1:200 of the reverse transcription reaction (final volume $10 \mu \mathrm{l}$ ), and were carried out on a ABI 7500 Sequence Detector (Applied Biosystems). Primers for cadherins and Hprt were designed with Primer Express software (Applied Biosystems), and their sequence specificity was then verified with the BLAST program. Primer sequences for cadherins and Hprt are given in Supplementary Table 1, see Supplementary data in the online version of the Journal of Endocrinology at http://joe.endocrinology-journals.org/cgi/content/full/ JOE-09-0153/DC1. Primer sequences for GH and GHRH-R were as previously described (Luque \& Kineman 2006). The final concentration of the primers was $300 \mathrm{nM}$. After an initial denaturation step for $10 \mathrm{~min}$ at $95^{\circ} \mathrm{C}$, the thermal cycling conditions were 40 cycles at $95^{\circ} \mathrm{C}$ for $15 \mathrm{~s}$ and $60{ }^{\circ} \mathrm{C}$ for $1 \mathrm{~min}$. For each sample, values were determined from triplicate measurements. Expression of cadherin transcripts was normalized to the expression level of the housekeeping gene Hprt, according to the formula $\mathrm{Cad} / \mathrm{Hprt}=\left(2^{-\left(C_{\mathrm{t}}(\mathrm{Cad})-C_{\mathrm{t}}(\mathrm{Hprt})\right)}\right) \times 1000$, where $C_{\mathrm{t}}$ is the threshold cycle. The optimum $C_{\mathrm{t}}$ was calculated by 7500 Real Time PCR System Sequence Detection software (Applied Biosystems) and represents the number of cycles obtained at $50 \%$ of PCR reaction linear phase (logarithmic scale). $C_{\mathrm{t}}$ for Hprt was about 24 cycles and remained constant between the different samples, i.e. the $C_{\mathrm{t}}$ value was not affected by the phase of development.

\section{Antibodies}

The primary antibodies used in this study were as follows: rabbit polyclonal against $\beta$-catenin (sc-7199, Santa Cruz Biotechnology, Santa Cruz, CA, USA); rabbit polyclonal against $\mathrm{N}$-cadherin (Calbiochem, La Jolla, CA, USA); rat monoclonal against E-cadherin (ECCD2, Takara Bio Inc., Otsu, Japan); rabbit polyclonal against cadherin-11 kindly provided by Dr R M Mege, University of Paris, France (Marthiens et al. 2002); rabbit polyclonal and mouse monoclonal against cadherin-8 kindly provided respectively, by Dr K Korematsu, Oita Prefectural Hospital, Oita, Japan (Korematsu et al. 1998) and $\operatorname{Dr} M$ Takeichi, RIKEN Center for Developmental Biology, Kobe, Japan (Suzuki et al. 2007); rabbit polyclonal against S100 (Sigma); and rabbit polyclonal against tubulin (Abcam, Cambridge, UK). Guinea pig polyclonal antibodies against each pituitary hormone were obtained from the National Hormone and Peptide Program, NIDDK and Dr A F Parlow, (Torrance, CA, USA). Rabbit polyclonal antibody against cadherin-18 was raised by immunizing rabbits with a synthetic peptide, corresponding to the $15 \mathrm{C}$-terminal amino acids, conjugated to keyhole limpet hemocyanin, and affinity purified using the same peptide. Specificity of the cadherin-18 antibody is shown in Supplementary Figure 1, see Supplementary data in the online version of the Journal of Endocrinology at http://joe.endocrinology-journals.org/cgi/ content/full/JOE-09-0153/DC1.

\section{Immunohistochemistry}

Cadherin immunostaining was performed according to the method described by Korematsu et al. (1998). Pituitaries were fixed in $4 \%$ paraformaldehyde in PBS supplemented with $1 \mathrm{mM} \mathrm{CaCl} 2$ for $3 \mathrm{~h}$ at $4{ }^{\circ} \mathrm{C}$. Then, $40 \mu \mathrm{m}$-thick sections were prepared with a vibratome. Thereafter, sections were washed in Tris-buffered saline containing $1 \mathrm{mM} \mathrm{CaCl} 2$ (TBS-Ca) and incubated for $48 \mathrm{~h}$ at $4{ }^{\circ} \mathrm{C}$ with the relevant primary antibodies in TBS-Ca containing $0 \cdot 1 \%$ Triton $\mathrm{X}-100$, and 2\% normal donkey serum (Sigma), with gentle agitation. After rinsing in TBS-Ca, sections were incubated for $2 \mathrm{~h}$ at $4{ }^{\circ} \mathrm{C}$ with appropriate secondary antibodies conjugated with either Alexa Fluor 488 (1:500, Molecular Probes, Eugene, OR, USA), Cy3 or Cy5 (1:1000 and 1/400 respectively, Jackson ImmunoResearch Laboratories, West Grove, PA, USA) in the same blocking solution, and finally carefully washed with TBS-Ca before mounting in Mowiol (Calbiochem). For Cadherin 18, immunostaining was performed on methanol-fixed cryostat sections obtained from unfixed frozen pituitary.

\section{Confocal microscopy}

Sections were observed under a LSM510 Zeiss Confocal laser scanning microscope equipped with a krypton/argon mixed gas laser as previously described (Chauvet et al. 2003). Briefly, three laser lines emitting at 488, 568, and $645 \mathrm{~nm}$ were used for exciting the eGFP or Alexa Fluor 488-, Cy3-, and Cy5-conjugated secondary antibodies respectively. The background noise of each confocal image was reduced by averaging eight image inputs. The organization of the immunostained structures was studied on reconstructed images made by projecting $z$-series of 3-4 consecutive confocal images $1 \mu \mathrm{m}$ apart. Unaltered digitalized images were transferred to a computer and Adobe Photoshop software was used to prepare final figures.

\section{Western blot analysis}

Total protein from adult anterior pituitary glands was extracted in lysis buffer $(50 \mathrm{mM}$ Tris, $\mathrm{pH} 7 \cdot 5,150 \mathrm{mM}$ $\mathrm{NaCl}, 2 \mathrm{mM}$ EDTA, 1\% Triton X-100, 0.05\% of SDS, protease inhibitor cocktail (Roche Diagnostics) $1.5 \mathrm{mM}$ phenylmethylsulphonyl fluoride). The extracts were spun in a centrifuge at $16000 \mathrm{~g}$ for $15 \mathrm{~min}$ at $4{ }^{\circ} \mathrm{C}$, and the supernatant protein concentration determined by Bradford assay. Total protein $(60 \mu \mathrm{g})$ for each sample was resolved on $7 \cdot 5 \%$ SDS-PAGE. Immunoblot analyzes were performed with primary antibody raised against cad18 (1:2000) followed by detection with HRP-conjugated secondary antibody (1:10 000; Jackson ImmunoResearch) and chemiluminescence. Membranes were reprobed with an $\alpha$-tubulin antibody (1:1000) to control lane loading. Intensities of cad18 bands were quantified using Image J software and normalized to those of $\alpha$-tubulin. 


\section{Results}

\section{Differential $\beta$-catenin expression in pituitary cell types}

$\beta$-Catenin is an obligatory intracellular component of all classic cadherin complexes and binds to the so-called catenin binding domain (Nagafuchi \& Takeichi 1989, Ozawa et al. 1990). In order to determine whether catenin/cadherin complexes were present in each endocrine pituitary cell type, we examined $\beta$-catenin distribution by immunohistochemistry on sections from adult pituitary gland double-stained with antibodies against $\beta$-catenin and the different hormones produced by the gland (GH, TSH, FSH, LH, ACTH, and PRL). Overall, $\beta$-catenin was strongly and broadly expressed throughout the gland. Although the staining was mainly present at the cell membrane, some cells showed both membranous and cytoplasmic signals (Fig. 1). Co-staining for $\beta$-catenin and the various pituitary hormones revealed that $\beta$-catenin signal location varied according to the endocrine cell type. The strongest and most homogeneous staining was observed in somatotrophs (Fig. 1A) and in TSH cells, where $\beta$-catenin labeling was detected both at the membrane and throughout the cytoplasm (Fig. 1B). By contrast, the signal was less intense in LH (data not shown) and FSH cells (Fig. 1C), where $\beta$-catenin staining was only present at portions of the cell membrane. ACTH cells were also moderately stained, with frequently discontinous membrane $\beta$-catenin labeling (Fig. 1D). PRL cells displayed less obvious staining that was mainly restricted to heterotypic contacts between PRL and other hormone-producing cells (Fig. 1E). Thus, while $\beta$-catenin expression was widespread and not restricted to one cell-type, its intensity of expression and cellular location differed markedly amongst the different cell types. It was most prominent in somatotrophs.

\section{Cadherin expression within the pituitary gland and purified $G H$} cells from puberty to adulthood

To explore the expression of classic cadherins in mouse pituitary gland and especially in somatotrophs, we took advantage of our GH-eGFP mouse model that allows the isolation of $\mathrm{GH}$ cells by FACS sorting from enzymatically dispersed cells. To validate GH cell purification by FACS, we measured $G h$ and Ghrh-R mRNA levels by real-time PCR in GH positive and GH negative cell populations obtained from 70-days-old male GH-eGFP mice. The mRNA encoding for Ghrh-R, known to be a GH cellspecific marker (Carmignac et al. 1996, Morel et al. 1999, McElvaine et al. 2007), was specifically detected in $\mathrm{GH}$ positive cells and was virtually absent from the $\mathrm{GH}$ negative cell population. In addition, $G h$ mRNA was 75-fold increased in the $\mathrm{GH}$ positive cell population. Altogether, these data indicate a successful separation between both cell populations by FACS. We then quantified multiple cadherin mRNA levels by real-time PCR in both GH positive and GH negative cell populations. Figure 2 shows that among the 13
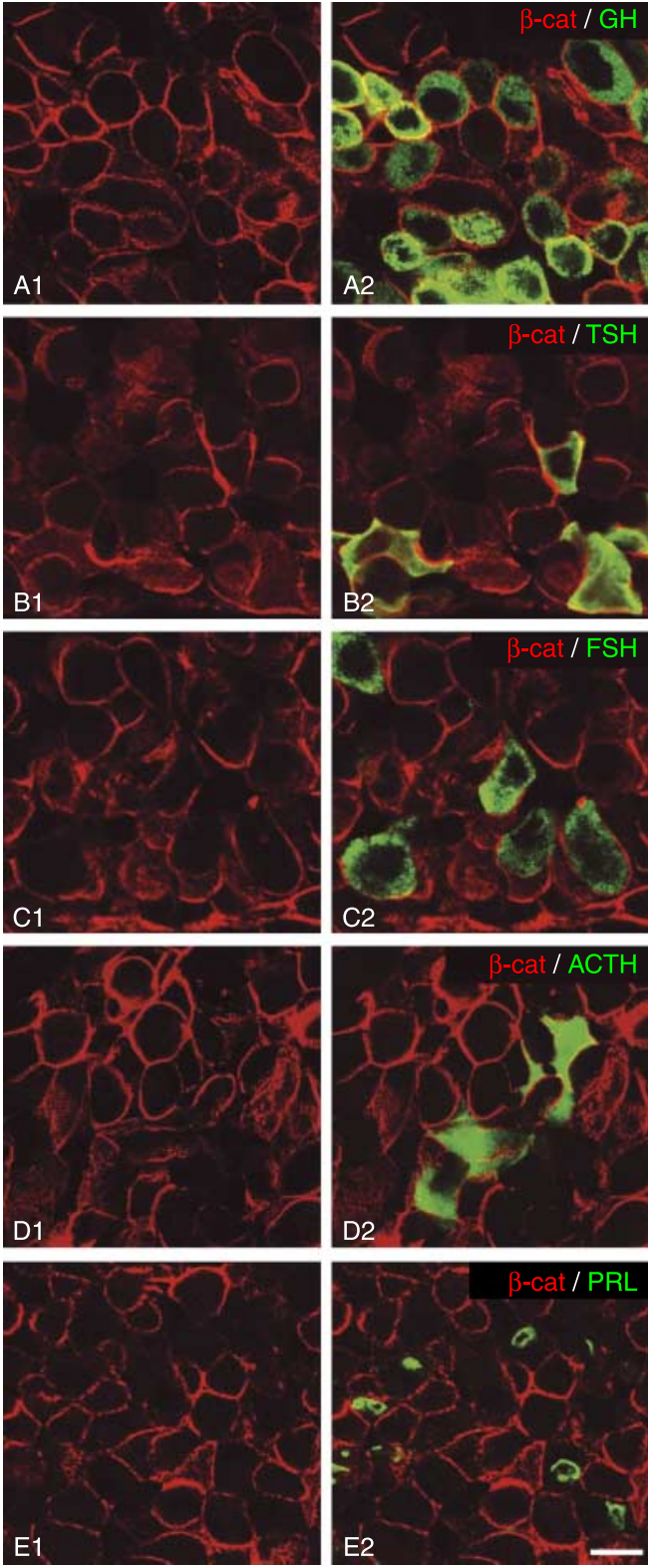

Figure $1 \beta$-Catenin distribution in the anterior pituitary from adult male mice. (A-E) $\beta$-Catenin distribution in hormone-producing cells of the anterior pituitary from adult (70 days) male mice. (A) Confocal images showing immunofluorescence labeling of pituitary sections from a GH-eGFP (green) male mouse with $\beta$-catenin antibody (red). (B-E) Confocal images showing double immunofluorescence labeling of pituitary sections with $\beta$-catenin antibody (red) and specific antibodies against TSH (B, green), $\mathrm{FSH}$ (C, green), $\mathrm{ACTH}$ ( $\mathrm{D}$, green), or $\operatorname{PRL}(\mathrm{E}$, green). To improve $\beta$-catenin staining visibility, the red channel is shown alone on the left. Although $\beta$-catenin expression was almost ubiquitous; its distribution was different amongst the various cell-types. In particular, $\mathrm{GH}$ cells showed the most homogenous and intense staining (A). Conversely, PRL cells displayed a weak $\beta$-catenin staining (E). Scale bar, $10 \mu \mathrm{m}$. Full colour version of this figure available via http://dx.doi.org/10.1677/JOE-09-0153. 


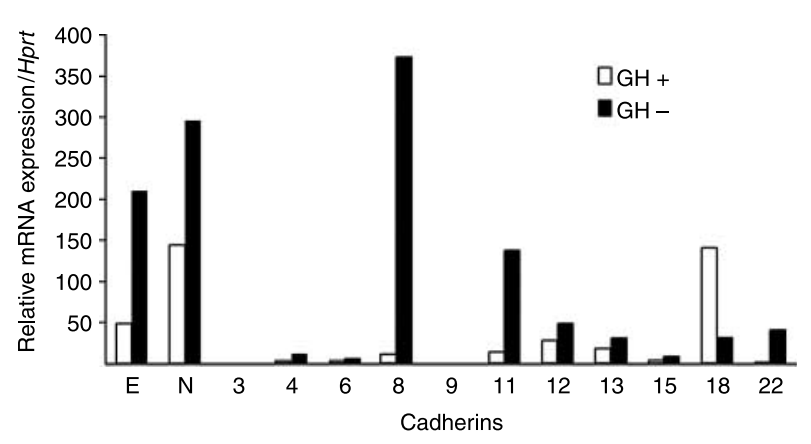

Figure 2 Cadherin expression profile in anterior pituitary from adult mouse. GH cells were isolated from 70-days-old GH-eGFP male mice by FACS analysis. Expression levels of mRNA encoding for classic cadherins were quantified by real-time PCR in $\mathrm{GH}$ positive cells $(\mathrm{GH}+)$ and $\mathrm{GH}$ negative cell population $(\mathrm{GH}-)$. Cadherin repertoire in mouse anterior pituitary was restricted and selective. $\mathrm{E}$-cad, $\mathrm{N}$-cad, and cad8, 11 and 18 were predominantly expressed.

cadherins tested, pituitary glands from 70-days-old mice expressed mainly E-cadherin (E-cad), N-cadherin (N-cad), cadherin-8, 11 and 18 (cad8, cad11, cad18), the other cadherins being absent or expressed at very low levels. Cad8 and cad11 were almost absent from somatotrophs. E-cad was detected mainly in the GH negative population, while N-cad was expressed in both $\mathrm{GH}$ positive and GH negative cell populations. Conversely, cad18 was most abundant in the GH positive population.

The selective patterning of cadherin mRNA at adulthood raises the possibility that it could be regulated across life span. It is well known that a marked increase in episodic GH secretion occurs at sexual maturation (Robinson \& Hindmarsh 1999) and at this time, the GH cell population exhibits marked spatial reorganization (Bonnefont et al. 2005). Hence, we measured mRNA levels of the most abundant cadherins in cells isolated by flow cytometry from GH-eGFP mice at various ages (pre and post pubertal animals and adult animals), and also investigated the cellular distribution of some of these cadherins by immunohistochemistry.

Although expression profile analysis of the cadherins by real-time PCR revealed that cad8 and cad 11 were present in the pituitary gland (Fig. 2), studies in GH positive and negative cell populations at various ages showed that these adhesion molecules were exclusively expressed in GH negative cells and did not undergo major modulations in expression between 15 and 150 days (Fig. 3A and B). To identify which other anterior pituitary cell types express cad8 and cad11, we attempted to perform specific immunohistochemistry for these cadherins. Despite using two different well-characterized antibodies to cad8 (Korematsu et al. 1998, Suzuki et al. 2007), which revealed expression in early postnatal striatum as previously described (Korematsu et al. 1998), we were unable to detect specific staining in the pituitary gland. By contrast, cad11 staining could be demonstrated, mainly localized in the cytoplasm of a few cells within the gland (Fig. 3C and D). No cad11-positive cells coexpressed GH (Fig. 3C) or ACTH, LH, FSH, and PRL (data not shown). Remarkably, all cad11-positive cells were thyrotrophs, but not all TSH cells expressed cad11 (Fig. 3D).

As noted above, E-cad was almost absent from adult somatotrophs (Fig. 2). The data shown in Fig. 3E confirm that E-cad (listed as Cdh1 in the MGI Database) mRNA levels were very low in $\mathrm{GH}$ cells at all ages. By contrast, E-cad was highly expressed in GH negative cells 15 days after birth, gradually decreasing until 70 days and remained stable at 150 days. In the adult pituitary, E-cad labeling was particularly intense at the boundary between the intermediate and anterior lobes, in the region composed of marginal layer cells that face the residual lumen of Rathke's pouch (Fig. 3F, arrowheads). E-CAD (CDH1) staining was also present in cells scattered throughout the gland (Fig. 3F, arrows), as previously reported by Kikuchi et al. (2006). Double immunostaining of sections with antibodies against the different hormones revealed that E-CAD staining was not associated with the endocrine cell population (data not shown). To further characterize the cells expressing E-CAD, sections were double immunostained with antibodies to E-CAD and S100 protein, a marker of marginal and FS cells (Nakajima et al. 1980, Shirasawa et al. 1983). E-CAD staining was restricted to marginal and FS cells (Fig. 3G and H), and within the anterior lobe, the labeling was limited to homotypic contacts between FS cells, and was absent from cell membrane domains involved in heterotypic FS contacts with hormone-producing cells (Fig. 3H).

$\mathrm{N}$-cad (Cdh2 as given in MGI Database) mRNA was present in both cell populations collected by FACS, being twofold higher in the $\mathrm{GH}$ negative than in the GH positive cell population (Fig. 4A). In both cell populations, $\mathrm{N}$-cad mRNA levels were twofold less abundant in 30-days-old mice than in 15-days-old animals, and then remained similar at 70 and 150 days. Simultaneous detection of pituitary hormones and N-CAD (CDH2) by immunohistochemistry showed that N-CAD could be detected in all adult endocrine cell types (Fig. 4B-E). As observed for $\beta$-catenin staining, the signal pattern and intensity varied among cell types. N-CAD staining was intense at the plasma membrane of GH (Fig. 4B), TSH (Fig. 4C), FSH (Fig. 4D), and LH (data not shown) cells, with GH cells showing the most homogeneous labeling, and was moderate in ACTH cells (Fig. 4E). In addition, some cytoplasmic staining for N-CAD was observed in TSH cells. $\mathrm{N}-\mathrm{CAD}$ staining was not obvious at homotypic contacts between PRL cells and was present at some heterotypic contacts between PRL and other hormone-producing cells (data not shown).

Cad18 (Cdh18 as listed in MGI Database) was the sole cadherin with mRNA levels much higher in the GH positive population than in the GH negative population (Figs 2 and 5A). At each age studied Cad 18 mRNA was expressed at very low levels in the GH negative population, and its relative expression in GH cells was highest at 15 days and then progressively decreased (twofold between 15 and 150-daysold animals). To further characterize CAD18 (CDH18) 

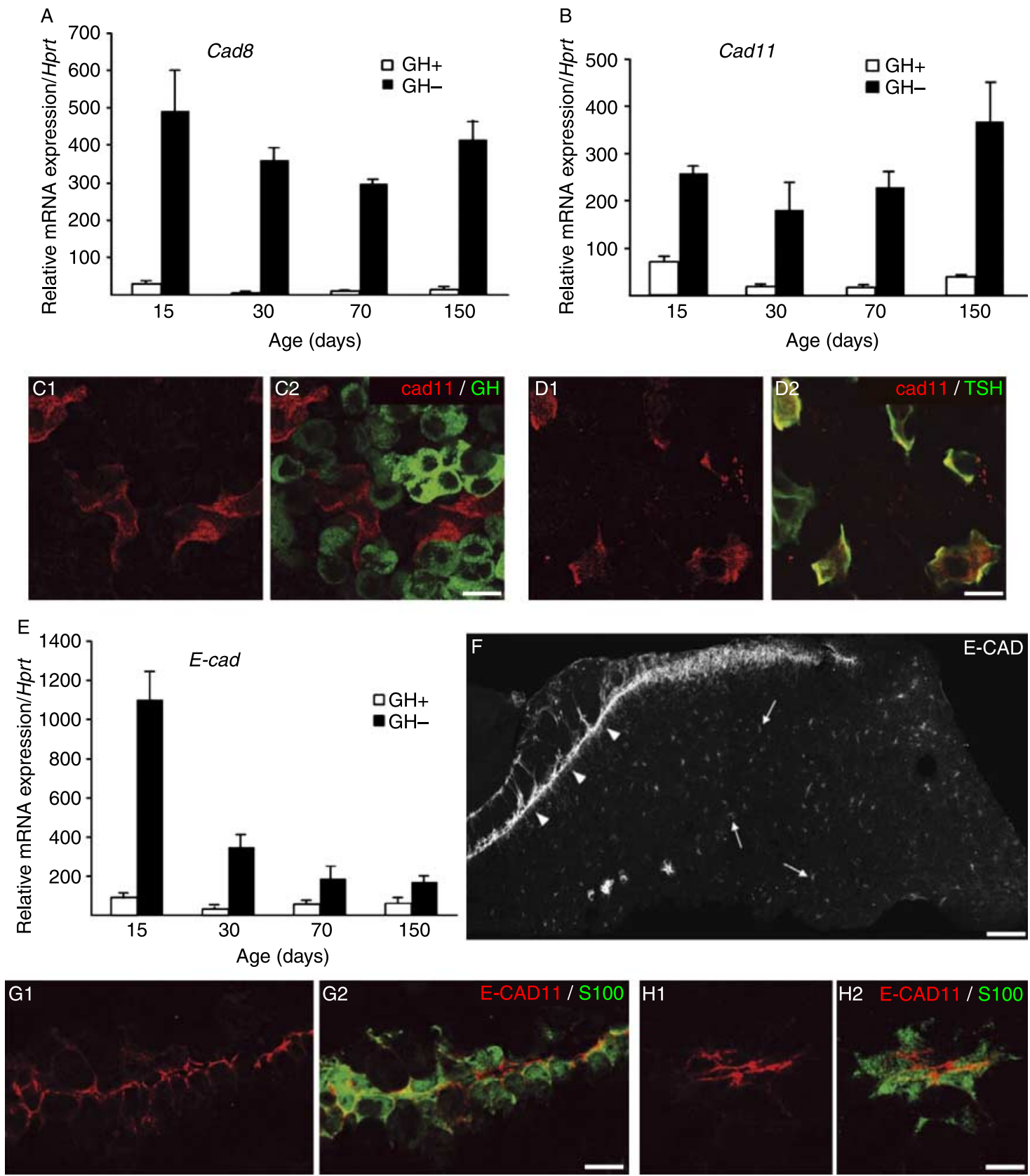

Figure 3 Expression and distribution of cadherins excluded from GH cells. (A and B) Relative Cad8 (A; listed as Cdh8 in MGI Database) and $\mathrm{Cad} 11$ (B; listed as Cdh11 in MGI Database) mRNA expression in GH + and GH - cell populations isolated by FACS analysis from 15 to 150 day-old $\mathrm{GH}$-eGFP male mice. mRNAs encoding for Cad8 and Cad11 were detected only in GH negative cell population and their expression levels did not show major modulation at all ages studied. (C and D) CAD11 distribution in GH (C) and TSH (D) cells. (C) Confocal images showing immunofluorescence labeling of pituitary sections from a GH-eGFP (green) male mouse (70 days) with CAD11 antibody (red). (D) Confocal images showing double immunofluorescence labeling of pituitary sections with CAD11 antibody (red) and specific antibody against TSH (green). CAD11 was specifically expressed in TSH cells. (E) Relative E-cad mRNA expression in $\mathrm{GH}+$ and $\mathrm{GH}$ - cell populations isolated by FACS analysis from 15 to 150 -days-old GH-eGFP male mice. E-cad mRNA was mainly expressed in $\mathrm{GH}$ negative cell population. Note its high expression level 2 weeks after birth. (F) Large-scale E-cad distribution in adult (70 days) male mouse pituitary obtained by montage of confocal images. E-CAD was localized in marginal layer cells that face the residual lumen of Rathke's pouch (arrowheads) and in cells scattered throughout the gland (arrows). (G and H) Confocal images showing double immunofluorescence labeling of pituitary sections from a 70-days-old male mouse with E-CAD antibody (red) and S100 antibody (green), a marker of marginal and FS cells. E-CAD was specifically detected in marginal cells $(\mathrm{G})$ and at homotypic contacts between FS cells (H). Scale bar in C, D, G and H, $10 \mu \mathrm{m} ; \mathrm{E}, 100 \mu \mathrm{m}$. Full colour version of this figure available via http://dx.doi.org/10.1677/JOE-09-0153. 
protein distribution at the protein level, we developed an antibody specifically directed against this protein (characterization of this antibody is available in Supplementary Figure 1). By western-blot analysis (Fig. 5B), this antibody
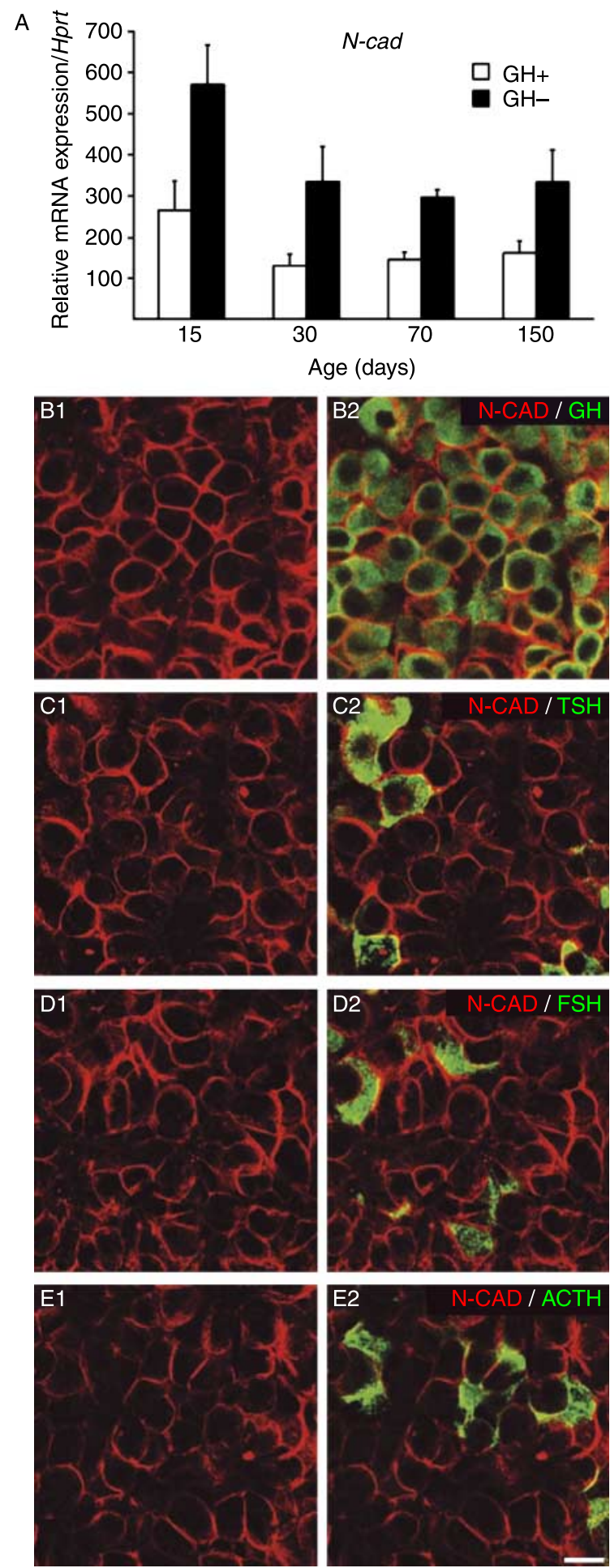

recognized a band at $115 \mathrm{kDa}$, the expected size for cad18 (Shimoyama et al. 1999), in extracts from the adenohypophysis obtained from wild-type animals. The intensity of this band was markedly reduced (almost 80\%) in adenohypophysis extracts from M2-GHRH mice, a model in which the GH cell population is strongly hypoplastic, as a consequence of GHRH neurons ablation by targeted expression of the M2 viral channel (Le Tissier et al. 2005). These results suggest that CAD18 was present mostly in GH cells. Immunostaining on cryostat sections from unfixed pituitary obtained from 70-days-old GH-eGFP animals revealed that a majority of GH-positive cells exhibited a moderate staining for CAD18 at their membrane surface, very often observed at cell-cell contacts between GH cells (Fig. 5C). Although CAD18 staining was mainly localized in GH cells, some labeling could also be detected in a few GH negative cells. Double immunostaining for CAD18 and pituitary hormones showed that CAD18 was absent at least from TSH and ACTH cells (Fig. 5D and E), since on this histological preparation, we were unable to detect $\mathrm{LH}, \mathrm{FSH}$, and prolactin hormones. Remarkably, some intense CAD18 staining was found at the boundary between the intermediate and anterior lobes (Fig. 5F), suggesting that marginal cells could express CAD18. Double immunostaining for E-CAD and CAD18 revealed that both were present in marginal cells where they displayed a differential distribution since they were only partially colocalized (Fig. 5F). Within the anterior lobe, E-CAD positive contacts between FS cells harbored CAD18 labeling (Fig. 5G).

\section{Cadherin expression within the pituitary gland during development}

Since the maturation of the GH and FS cell networks takes place during the embryonic and postnatal period, we examined postnatal changes in $\mathrm{E}, \mathrm{N}$, and CAD18 expressions by real-time PCR and immunohistochemistry. Analysis of Cad18 mRNA expression using whole glands revealed that it was expressed at very low levels during the first postnatal week: its relative expression was around 35-40 in glands from P1 to P6 animals. By contrast, $N$-cad mRNA

Figure 4 Expression and distribution of $\mathrm{N}$-cadherin in the anterior pituitary from male mice. (A) Relative $\mathrm{N}$-cad mRNA expression in $\mathrm{GH}+$ and $\mathrm{GH}$ - cell populations isolated by FACS analysis from 15 to 150-days-old GH-eGFP male mice. $\mathrm{N}$-cad was expressed in both cell populations, and was about twofold higher 2 weeks after birth than at all the other ages studied. (B-E) N-CAD distribution in hormone-producing cells of the anterior pituitary from adult (70 days) male mice. (B) Confocal images showing immunofluorescence labeling of pituitary sections from a GH-eGFP (green) male mouse with N-CAD antibody (red). (C-E) Confocal images showing double immunofluorescence labeling of pituitary sections with N-CAD antibody (red) and specific antibodies against TSH (C, green), FSH (D, green), or ACTH (E, green). Although N-CAD distribution was relatively ubiquitous, $\mathrm{GH}$ cells showed the most remarkable N-CAD staining. Scale bar, $10 \mu \mathrm{m}$. Full colour version of this figure available via http://dx.doi.org/10.1677/JOE-09-0153. 

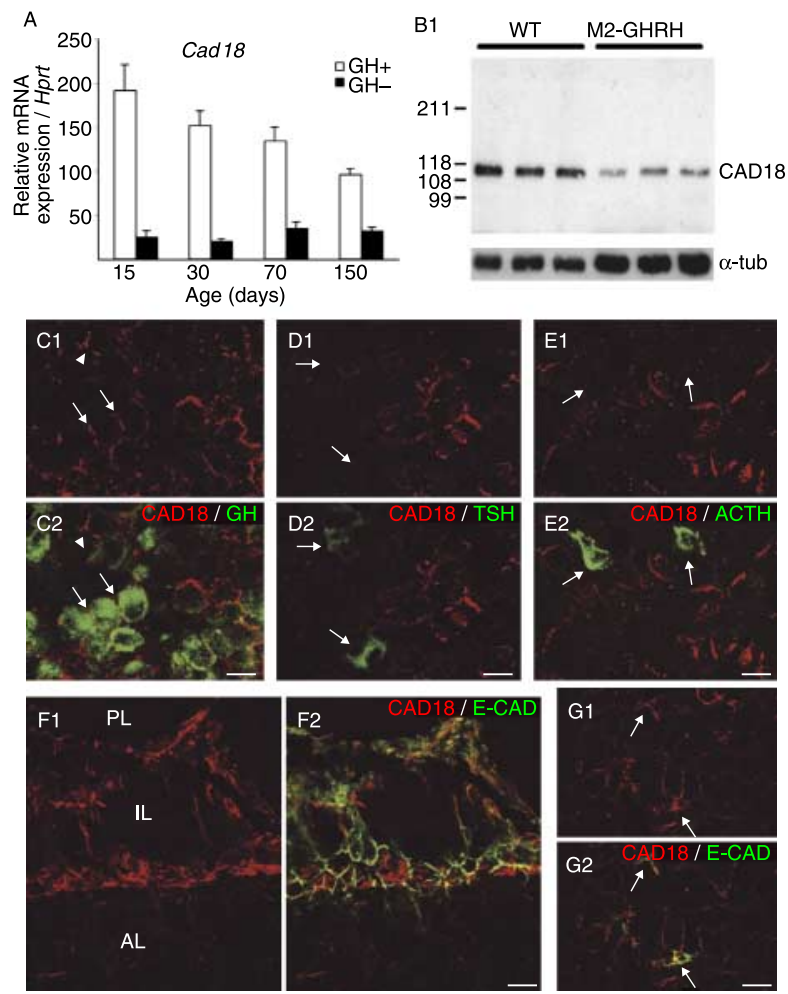

Figure 5 Expression and distribution of CAD18 in the anterior pituitary from male mice. (A) Relative Cad18 mRNA expression in $\mathrm{GH}+$ and $\mathrm{GH}-$ cell populations isolated by FACS analysis from 15 to 150-days-old GH-eGFP male mice. At each age studied, Cad18 was expressed at higher levels in $\mathrm{GH}+$ cells than in $\mathrm{GH}-$ cells. Note the progressive decrease in Cad18 expression from 15 to 150 days. (B) Western blot analysis of CAD18 protein in anterior pituitary extract from wild-type and M2-GHRH 70-day old male mice (B1). Membrane was reprobed with an alpha-tubulin antibody to control lane loading (B2). The $115 \mathrm{kDa}$ band recognized by CAD18 polyclonal antibody was greatly reduced in adenohypophysis from M2-GHRH compared with wild-type animals. (C) Confocal images showing immunofluorescence labeling of pituitary sections from a GH-eGFP (green) male mouse (70-days-old) with CAD18 antibody (red). Arrows show CAD18 staining at membrane contacts between $\mathrm{GH}$ cells. Note that a few CAD18-positive cells were GFP-negative (arrowhead). (D and E) Confocal images showing double immunofluorescence labeling of pituitary sections with CAD18 antibody (red) and specific antibodies against TSH (D, green), or ACTH (E, green). TSH and ACTH cells were devoid of CAD18 staining. ( $F$ and G) Confocal images showing double immunofluorescence labeling of pituitary sections from a male mouse with CAD1 8 antibody (red) and E-CAD antibody (green). CAD18 was expressed in marginal cells labeled with E-CAD antibody (F). CAD18 immunolabeling was also present at E-CAD positive contacts between FS cells (G, arrows). $\mathrm{PL}$, posterior lobe; IL, intermediate lobe; $\mathrm{AL}$, anterior lobe. Scale bar, $10 \mu \mathrm{m}$. Full colour version of this figure available via http://dx. doi.org/10.1677/JOE-09-0153.

was highly expressed at $\mathrm{P} 1$, and then progressively decreased to reach a nadir at sexual maturity (Fig. 6A); a similar decreasing profile was observed for E-cad (Fig. 6B). Clearly, therefore, various cadherins are regulated differentially during postnatal pituitary growth. However, the decline in $E$ - and $N$-cad mRNA expressions from birth prompted us to look at their cellular distribution in the pituitary during earlier development.

We thus examined $\mathrm{N}$ - and E-CAD distribution from E15.5, when GH cells appear and begin to be organized, to P10 (Fig. 6C-L). At E15.5, N-CAD staining was the most intense in the ventral part and at the periphery of the lateral wings of the adenohypophysis, while the central part of the gland exhibited a weak to negative labeling (Fig. 6C). From E18.5 to P1, N-CAD staining expanded throughout the gland (Fig. 6E and G), and after birth, the intensity of this uniform staining decreased (Fig. 6I and K), in accordance with the mRNA level measurements (Fig. 6A). By contrast, a different pattern of expression prevails for E-CAD. An intense and broad labeling was observed at E15.5 (Fig. 6D). By E18.5, some areas within the gland, especially in ventral and lateral regions, had lost this intense labeling (Fig. 6F). The decrease in E-CAD was even more apparent by birth (Fig. 6H), with the staining most intense in the remnants of Rathke's pouch lining cells, and in some patches of cells dispersed throughout the gland. Furthermore, these patches could be seen to be linked together and to Rathke's pouch by moderatly E-CAD positive rows of cells. At P4 and P10, E-CAD staining was further decreased, with immunoreactivity only maintained in the residual Rathke's pouch and in a few cells scattered throughout the gland (Fig. 6J and L). Interestingly, this pattern of expression observed at P10 was similar to the adult distribution. Altogether, these results indicate that, during embryonic stages, E- and N-CAD displayed very distinct changes in their expression patterns, with a progressive switch between E- and N-CAD expressions.

In order to establish the relationships between the drastic changes observed in E-CAD distribution and the ontogenesis as well as the topology of the hormone-producing cells, we performed simultaneous immunodetection for both E-CAD and hormones. The appearance of pituitary endocrine cells follows a well-described temporal sequence (Japon et al. 1994, Zhu et al. 2007). At E15.5, the earliest embryonic stage studied, the gland contains corticotrophs, the first pituitary cell type to reach terminal differentiation at this time, and immature somatotrophs (Bonnefont et al. 2005). At this stage, the majority of $\mathrm{GH}$ cells were strongly labeled for E-CAD (Fig. 7A). Remarkably, most ACTH cells located at the ventral and lateral surface of the gland were almost devoid of E-CAD, whereas the few cells distributed deeper within the adenohypophysis showed a strong to moderate labeling (Fig. 7A). At E18.5, E-CAD was maintained in the majority of GH cells, but was absent from most, if not all, ACTH cells (Fig. 7B). We also examined E-CAD staining in TSH and LH/FSH cells that appear between E15.5 and E18.5. Most TSH cells expressed E-cad (Fig. 7C), while a small proportion of LH/FSH cells were labeled (Fig. 7D). At birth, a substantial proportion of $\mathrm{GH}$ and TSH cells were still immunopositive for E-CAD and were in close contact with strongly E-CAD positive cells, together forming either the cell ensembles or 
the rows of cells as previously described (Fig. 7E and F; Supplementary Movie, see Supplementary data in the online version of the Journal of Endocrinology at http://joe. endocrinology-journals.org/cgi/content/full/JOE-09-0153/ DC1). Conversely, LH cells (Fig. 7G), FSH, and ACTH cells (data not shown) lacked E-CAD staining. These results thus indicate that, at birth, the GH cell network and TSH
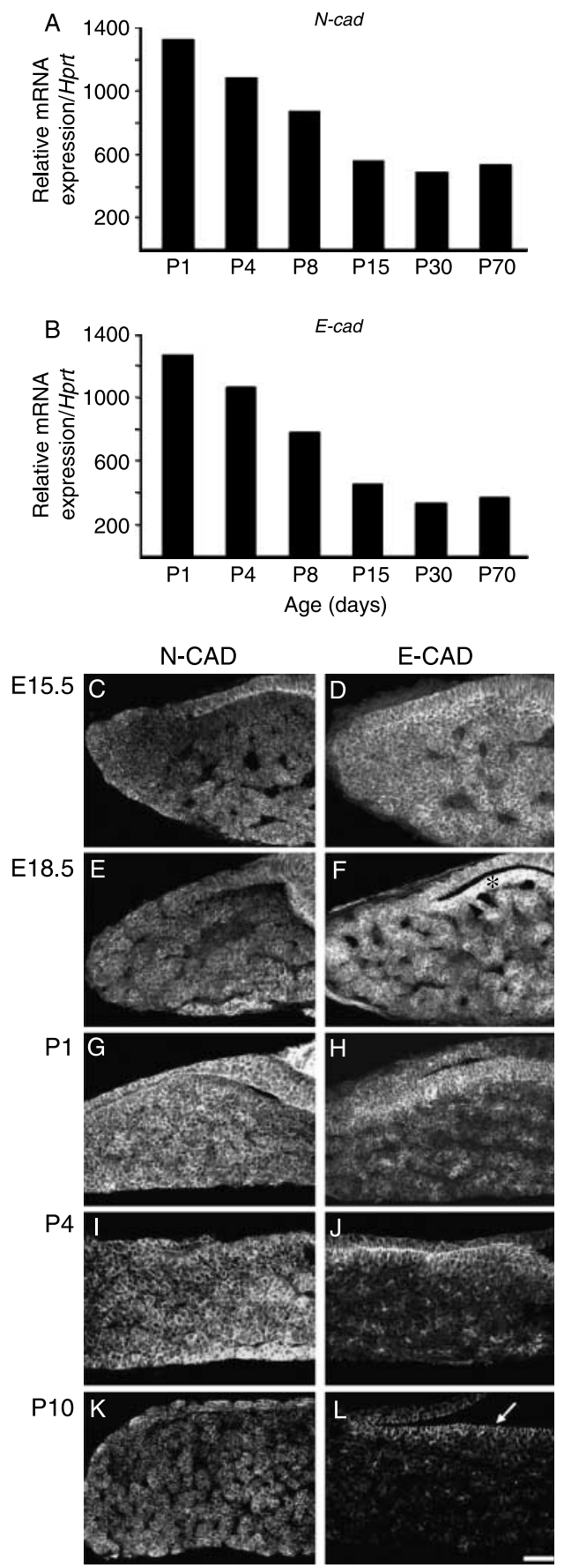

www.endocrinology-journals.org cells were associated with the specific E-CAD distribution pattern, while LH/FSH and ACTH cells were not.

During pituitary development, a switch between E- and $\mathrm{N}-\mathrm{CAD}$ expressions is observed within the gland (Fig. 6C-L; Kikuchi et al. 2007). However, the pattern of E-CAD distribution differs between endocrine cell types (Fig. 7). Thus, we further examined the differential expression of both cadherins within the various hormone-secreting cells (Fig. 8). At E15.5, GH cells expressed E-CAD at a high level, while N-CAD staining first appeared in GH cells located within the ventro-lateral part of the gland (Fig. 8A, arrows). By contrast, ACTH cells exhibiting no or very low labeling for $\mathrm{E}-\mathrm{CAD}$ were $\mathrm{N}-\mathrm{CAD}$ positive (Fig. $8 \mathrm{~B}$, arrowhead), and only a few cells coexpressed both E- and N-CAD (Fig. 8B, asterisks). At E18.5, N-CAD staining increased in the entire gland (as shown in Fig. 6E) and colocalized with E-CAD in the majority of $\mathrm{GH}$ and TSH cells (Fig. 8C and D). Conversely, LH/FSH cells that stained very weakly for E-CAD were strongly labeled for N-CAD (Fig. 8E, arrowheads). Altogether, these results indicate that $\mathrm{N}-\mathrm{CAD}$ appearance and $\mathrm{E}-\mathrm{CAD}$ loss occur with differential temporal sequences in the various cell types.

\section{Discussion}

We report here that the murine anterior pituitary gland expresses a restricted repertoire of classic cadherins since only five proteins were detected: E- and N-CAD; CAD8; 11; and 18. Interestingly, the cadherin expression profile is cell-type specific. CAD11 is specifically expressed in TSH cells, and E-CAD is a molecular component of the FS cell network. CAD18 is expressed in somatotrophs, marginal, and FS cells. $\mathrm{N}-\mathrm{CAD}$ exhibits an ubiquitous expression pattern, however, with different levels of expression between endocrine cell types. Thus, each cellular type is characterized by a specific cadherin expression pattern that can undergo major modulations during pituitary tissue remodeling events.

Figure 6 Cadherin expressions during embryonic and postnatal pituitary growth. (A and B) Relative $N$-cad and $E$-cad mRNA expressions in whole pituitary gland from P1 to P70 animals. Note the $\mathrm{N}$-cad and $E$-cad strong expression at birth. (C-L) N-CAD and E-CAD distribution in pituitary gland during embryonic and postnatal development. Confocal images showing immunofluorescence labeling with N-CAD (left column) or E-CAD (right column) of pituitary sections from E15.5 (C and D), E18.5 (E and F), P1 ( $\mathrm{G}$ and $\mathrm{H}$ ), P4 (I and J), and P10 ( $\mathrm{K}$ and $\mathrm{L}$ ) mice. From E15.5 to P1, a switch between $\mathrm{E}$ - and N-CAD expressions occurred. N-CAD staining appeared first in the ventral and the most lateral part of the gland $(C)$, and then extended towards the center (E), to finally be homogenously distributed throughout the gland at birth (G). By contrast, E-CAD labeling was initially intense and homogenous (D) and decreased progressively to lead to a peculiar E-CAD distribution pattern at E18.5 (F) and P1 $(\mathrm{H})$. Asterisk in F shows the Rathke's pouch. After birth, the signal intensity of both cadherins diminished ( $\mathrm{I}-\mathrm{L})$. Arrow in $\mathrm{L}$ indicates the residual Rathke's pouch. Scale bar, $50 \mu \mathrm{m}$. 

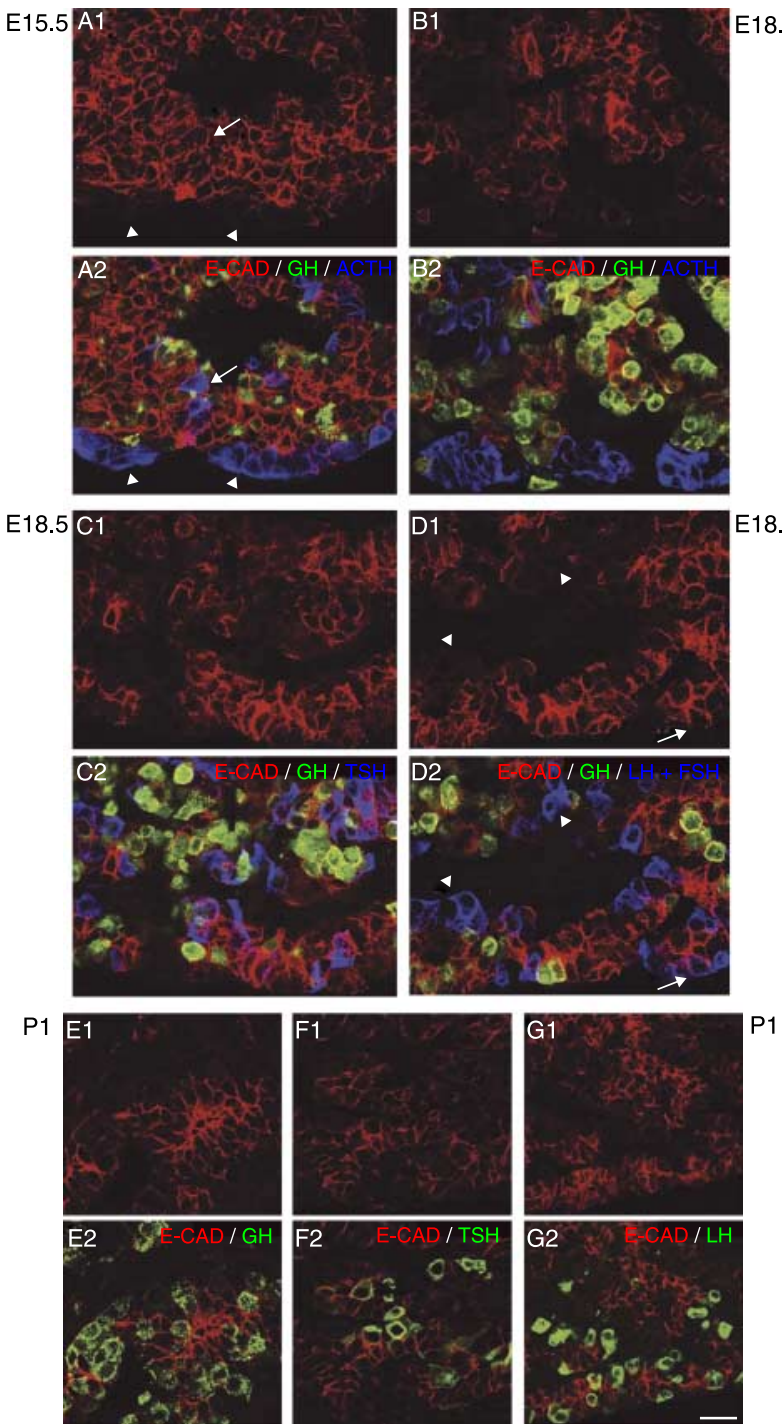

Figure 7 Distinct temporal sequence of E-CAD loss according to cell lineage. (A and B) Double immunofluorescence labeling of pituitary sections from GH-eGFP (green) mice with E-CAD (red) and ACTH (blue) antibodies at E15.5 (A) and E18.5 (B). At E15.5, all GH cells displayed an intense E-CAD staining. By contrast, the vast majority of corticotrophs lacked E-CAD (arrowheads), except a few ACTH cell located within the gland that was E-CAD positive (arrows). At E18.5, all ACTH cells have lost E-CAD, while GH cells still expressed this adhesion molecule. (C and D) Double immunofluorescence labeling of pituitary sections from E18.5 GH-eGFP (green) mice with E-CAD (red) and $\mathrm{TSH}(\mathrm{C}$, blue) or LH+FSH (D, blue) antibodies. TSH cells, like GH cells, expressed E-CAD $(\mathrm{C})$, while most of gonadotrophs were $\mathrm{E}-\mathrm{CAD}$ negative (arrowheads, D). Arrow in D points to an E-CAD positive gonadotroph cell. (E-G) Confocal images of pituitary sections from $\mathrm{P} 1$ mice expressing $(\mathrm{E})$ or not $(\mathrm{F}$ and $\mathrm{G}) \mathrm{GH}$-eGFP (green) stained with E-CAD (red) and either TSH (F, green) or $\mathrm{LH}$ (G, green) antibodies. While LH cells have lost E-CAD, GH and TSH cells still exhibited E-CAD moderate staining. Scale bar, $20 \mu \mathrm{m}$. Full colour version of this figure available via http://dx.doi. org/10.1677/JOE-09-0153.

\section{Cadherin expression repertoire displays plasticity}

A specific pattern of cadherin expression identifying different cell types seems to emerge very early during development. Indeed, we showed that the various endocrine cell types undergo a differential temporal control of switching of expression from E-CAD to N-CAD. Interestingly, we observed a rapid and concomitant E-CAD loss and N-CAD appearance in ACTH and LH/FSH cells, while in GH and TSH cells, E-CAD loss was delayed, with both molecules co-expressed before E-CAD disappeared. Thus, distinct cellspecific cadherin expression profiles are specified during pituitary development.

It is worth noting that cadherin subtype switching during anterior pituitary development is dependent on cell lineage. Signaling between and within the developing hypothalamic and pituitary tissues initiates transcription factor-mediated programs of cell proliferation and differentiation that establish the hormone-secreting cell profiles of the mature gland (Watkins-Chow \& Camper 1998, Drouin 2006). Hence, GH and TSH cells belong to the same cell lineage since they derive from a common Pit1-positive precursor, while ACTH and LH/FSH cells originate from distinct cell lineages. Thus, the mechanisms underlying cadherin switching may involve cell lineage-specific regulator factors, and are probably highly complex since cadherin expression and activity can be modulated by various mechanisms including transcriptional and posttranscriptional regulation (for review, see Halbleib \& Nelson (2006)). Whether E-CAD loss and/or N-CAD appearance, is/are necessary for the onset of hormone production is unknown. In the pancreas, N-CAD appears concomitantly with hormone synthesis during endocrine cell differentiation (Esni et al. 2001).

Many studies of development have demonstrated that cell adhesion molecules are expressed under a precise spatial and temporal control: appearance or loss of cadherins has been described as being generally correlated with morphogenetic events such as rearrangements, segregation, or association of cells (Hatta et al. 1987, Rukstalis \& Habener 2007). Indeed, subtype switching is a prominent physiological feature of cadherin morphogenetic function during development, especially when epithelial-mesenchymal transition (EMT) takes place (Halbleib \& Nelson 2006). During EMT, cells showing cadherin subtype switching are able to delaminate from the tissue and migrate over long distances (Acloque et al. 2008). Thus, EMT, a crucial process involved in tissue remodeling and cell migration, may play a major role in anterior pituitary organogenesis, and cadherins may be involved in this process as recently suggested by Himes \& Raetzman (2009).

Putative role of cell-type specific cadherin expression patterns in network formation and function

This study has shown that each pituitary cell type in the adult can be characterized by a unique cadherin expression profile. Numerous studies devoted to the multiple roles of cadherins 


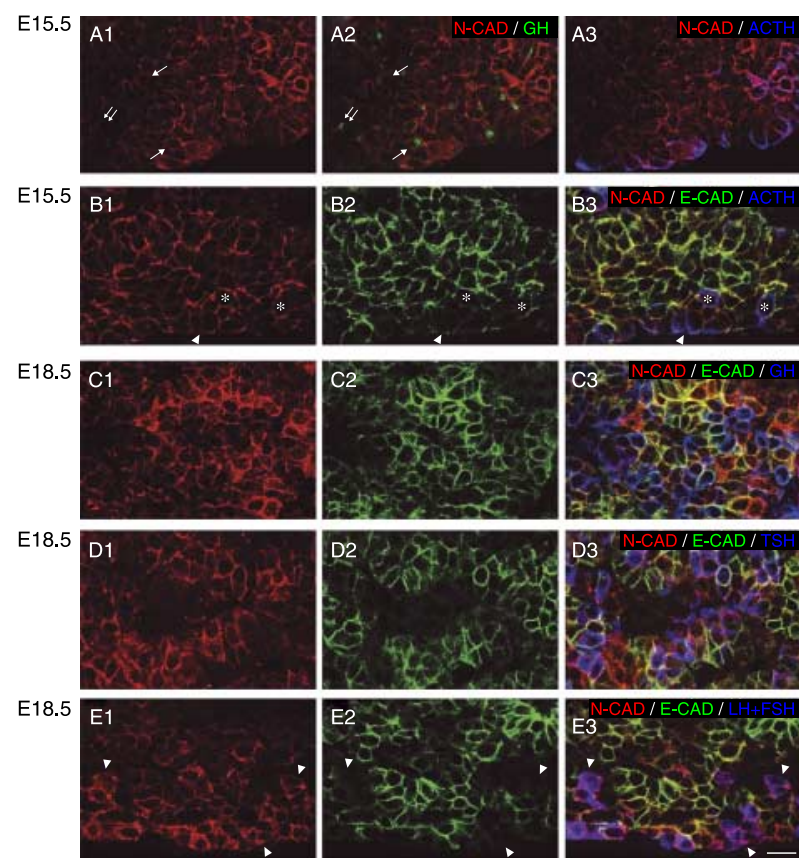

Figure 8 Distinct temporal sequence of $\mathrm{E}$ - to N-CAD switching according to cell lineage. (A) Double immunofluorescence labeling of pituitary sections from GH-eGFP (green) mice with N-CAD (red) and ACTH (blue) antibodies at E15.5. (B) Triple immunofluorescence labeling of pituitary sections with N-CAD (red), E-CAD (green) and ACTH (blue) antibodies at E15.5. N-CAD appeared in $\mathrm{GH}$ cells located in the periphery of the gland (A, arrows), while cells present in the center of the gland did not express N-CAD (A, doublearrow). Conversely, ACTH cells devoid of E-CAD were clearly labeled for N-CAD (B, arrowhead), and a few cells coexpressed E- and N-CAD (B, asterisks). (C-E) Triple immunofluorescence labeling of pituitary sections with N-CAD (red), E-CAD (green) and $\mathrm{GH}$ (C, blue), TSH (D, blue) or $\mathrm{LH} / \mathrm{FSH}$ (E, blue) antibodies at E18.5. N-CAD staining colocalized with E-CAD in the majority of $\mathrm{GH}$ and TSH cells ( $\mathrm{C}$ and $\mathrm{D}$ ). By contrast, gonadotrophs were strongly labeled for N-CAD but almost devoid of E-CAD (E, arrowheads). Scale bar, $20 \mu \mathrm{m}$. Full colour version of this figure available via http://dx.doi.org/10.1677/JOE-09-0153.

during neuromorphogenesis have shown that the complexity of the pattern of cadherin expression increases with brain development and defines specific neural circuits (Redies et al. 2003, Suzuki \& Takeichi 2008). More precisely, some brain structures expressing the same cadherin subtype are functionally related and connected by fiber tracts (Suzuki et al. 1997). The existence of cell-type specific cadherin expression has also been reported in the testis where cell adhesion is likely to be of critical importance for spermatogenesis (Johnson et al. 2000, Johnson \& Boekelheide 2002). All testis cell types express one or more cadherin family members, and each cell type can be differentiated by its unique cadherin expression profile.

The cell-type specific cadherin profiles could play an important role in pituitary cell specification. It has been found that, besides the crucial role played by homophilic binding specificity in determining cell-sorting behavior (Gumbiner 2005, Halbleib \& Nelson 2006), the level of cadherin expression, and therefore the strength of cell adhesion, influence cell-sorting, independently of the type of cadherin expressed (Duguay et al. 2003, Foty \& Steinberg 2005). Distinct cadherin expression repertoires could lead to specific cadherin-mediated signaling events or quantitative differences in adhesion, and in turn could contribute to the process of intercellular recognition. It is interesting to note that somatotrophs, which express high levels of N-CAD, are strongly cohesive when they are organized in clusters (Bonnefont et al. 2005), suggesting that N-CAD may participate in the segregation of pituitary endocrine cells. By ensuring a strong cohesion between somatotrophs, $\mathrm{N}-\mathrm{CAD}$ could also be involved in the robustness of the network. Therefore, N-CAD could be an architectural component of the $\mathrm{GH}$ cell network and its fate in the adulthood. Furthermore, E-CAD, which is present only in marginal cells and at contacts between FS cells, may have an important role in the maintenance of FS cell network architecture via its function in cadherin-mediated cell adhesion. On the other hand, CAD18, which is expressed in FS and GH cells, could be involved in the maintenance of both networks and potentially participate in heterotypic contacts between FS cells and GH cells. The presence of CAD11 exclusively in TSH cells suggests that this cell type may also be organized within the pituitary, via CAD11-mediated cell adhesion. Regarding PRL cells, their three-dimensional organization (Mollard \& Le Tissier unpublished data) may rely on different cell/cell communication mechanisms, since $\beta$-catenin and N-CAD distribution in these cells differ strikingly from the other pituitary cell types.

In conjunction with their role in the formation of cellular networks, cadherins may be involved in their functional organization. CAD18 expression in GH cells is low during the perinatal period and is increased as GH becomes important in terms of growth. This suggests that this cell adhesion molecule may not be crucial during development, but rather may play a role during sexual maturation when GH network undergoes profound remodeling and plasticity (Bonnefont et al. 2005). Atsumi \& Takeichi (1980) first suggested that cadherin must be present for the genesis of the gap junctions, and it is now well recognized that cadherins play a critical role in connexin assembly, trafficking and functional gap junction cellular coupling (Giepmans 2004, Li et al. 2006). Gap junctions provide intercellular communication within the FS cell network (Soji et al. 1997) and, interestingly, are associated with its development and maturation: in male rats, in parallel to the FS network formation (starting 10 days after birth), a concomitant increase in the number of gap junctions in each follicle is observed with a maximum in 40-days-old animals (Soji et al. 1997). E-CAD distribution observed 10 days after birth is identical to the adult pattern, suggesting that this molecule may have a role in the formation of the FS network. Since cadherin-mediated cell-cell adhesion is a prerequisite for 
formation of gap junctions (Hertig et al. 1996, Giepmans 2004), one can speculate that E-CAD could play a role in gap junction establishment between FS cells, and therefore E-CAD could participate in the function of the FS cell network.

In summary, the present study shows that each pituitary cell type exhibits a unique and dynamic cadherin expression profile. The characteristic presence or absence of various adhesion molecules in distinct cell types, as well as their level of expression, could constitute a qualitative and quantitative cellular bar code that may participate both in the differential segregation of anterior pituitary cells, and in the establishment and maintenance of their cellular network organization. It is possible that alteration of this code may lead to disturbance in gland function and organization in pathological conditions. In addition, gland formation is associated with cell-specific spatial and temporal changes in cadherin expression. These results suggest that pituitary development involves morphogenetic events (cell sorting, migration, EMT...), which have been described in highly organized organs such as the brain but still not identified in the pituitary gland. These highly dynamic and plastic events presumably rely on cadherin expression and activity, but also probably require a more complex cellular pattern of expression enabling multiple communication pathways to work in concert.

\section{Declaration of interest}

The authors declare that there is no conflict of interest that could be perceived as prejudicing the impartiality of the research reported.

\section{Funding}

This work was supported by grants from Institut National de la Santé et de la Recherche Médicale, Centre National de la Recherche Scientifique, Ministère de l'Enseignement Supérieur et de la Recherche, Région Languedoc-Roussillon, and ANR-06-blan-032.

\section{Acknowledgements}

We thank Drs Xavier Bonnefont, Nathalie Guérineau, David Hodson, and Agnès Martin for helpful discussions in preparing the manuscript, and Dr Annie Varrault and Elodie Gavois for their invaluable assistance. We thank Montpellier RIO Imaging-Centre Régional d'Imagerie Cellulaire plateform and Dr Christophe Duperrey for FACS analysis. We also thank Drs M Takeichi (RIKEN Center for Developmental Biology, Kobe, Japan), A F Parlow (Torrance, CA), K Korematsu (Oita Prefectural Hospital, Oita, Japan), and R M Mege (University of Paris 6, France) for antibody gifts.

\section{References}

Acloque H, Thiery JP \& Nieto MA 2008 The physiology and pathology of the EMT. Meeting on the epithelial-mesenchymal transition. EMBO Reports 9 322-326.
Allaerts W, Mignon A \& Denef C 1991 Selectivity of juxtaposition between cup-shaped lactotrophs and gonadotrophs from rat anterior pituitary in culture. Cell and Tissue Research 263 217-225.

Atsumi T \& Takeichi M 1980 Cell association pattern in aggregates controlled by multiple cell-cell adhesion mechanisms. Development, Growth \& Differentiation 22 133-142.

Bonnefont X, Lacampagne A, Sanchez-Hormigo A, Fino E, Creff A, Mathieu MN, Smallwood S, Carmignac D, Fontanaud P, Travo P et al. 2005 Revealing the large-scale network organization of growth hormonesecreting cells. PNAS 102 16880-16885.

Bosco D, Rouiller DG \& Halban PA 2007 Differential expression of E-cadherin at the surface of rat beta-cells as a marker of functional heterogeneity. Journal of Endocrinology 194 21-29.

Carmignac DF, Flavell DM \& Robinson IC 1996 Pituitary growth hormone-releasing factor receptor expression in normal and dwarf rats. Neuroendocrinology 64 177-185.

Carvell MJ, Marsh PJ, Persaud SJ \& Jones PM 2007 E-cadherin interactions regulate beta-cell proliferation in islet-like structures. Cellular Physiology and Biochemistry 20 617-626.

Chauvet N, Prieto M, Fabre C, Noren NK \& Privat A 2003 Distribution of p120 catenin during rat brain development: potential role in regulation of cadherin-mediated adhesion and actin cytoskeleton organization. Molecular and Cellular Neurosciences 22 467-486.

Dahl U, Sjodin A \& Semb H 1996 Cadherins regulate aggregation of pancreatic beta-cells in vivo. Development 122 2895-2902.

Denef C 2008 Paracrinicity: the story of 30 years of cellular pituitary crosstalk. Journal of Neuroendocrinology 20 1-70.

Denef C, Maertens P, Allaerts W, Mignon A, Robberecht W, Swennen L \& Carmeliet P 1989 Cell-to-cell communication in peptide target cells of anterior pituitary. Methods in Enzymology 168 47-71.

Drouin J 2006 Molecular mechanisms of pituitary differentiation and regulation: implications for hormone deficiencies and hormone resistance syndromes. Frontiers of Hormone Research 35 74-87.

Duguay D, Foty RA \& Steinberg MS 2003 Cadherin-mediated cell adhesion and tissue segregation: qualitative and quantitative determinants. Developmental Biology 253 309-323.

Esni F, Johansson BR, Radice GL \& Semb H 2001 Dorsal pancreas agenesis in N-cadherin- deficient mice. Developmental Biology 238 202-212.

Ezzat S \& Asa SL 2005 The molecular pathogenetic role of cell adhesion in endocrine neoplasia. Journal of Clinical Pathology 58 1121-1125.

Fauquier T, Guerineau NC, McKinney RA, Bauer K \& Mollard P 2001 Folliculostellate cell network: a route for long-distance communication in the anterior pituitary. PNAS $988891-8896$.

Fauquier T, Lacampagne A, Travo P, Bauer K \& Mollard P 2002 Hidden face of the anterior pituitary. Trends in Endocrinology and Metabolism 13 304-309.

Foty RA \& Steinberg MS 2005 The differential adhesion hypothesis: a direct evaluation. Developmental Biology 278 255-263.

Giepmans BN 2004 Gap junctions and connexin-interacting proteins. Cardiovascular Research 62 233-245.

Gubkina O, Cremer H \& Rougon G 2001 Mutation in the neural cell adhesion molecule interferes with the differentiation of anterior pituitary secretory cells. Neuroendocrinology 74 335-346.

Guerineau NC, Bonnefont X, Stoeckel L \& Mollard P 1998 Synchronized spontaneous $\mathrm{Ca}^{2+}$ transients in acute anterior pituitary slices. Journal of Biological Chemistry 273 10389-10395.

Gumbiner BM 2005 Regulation of cadherin-mediated adhesion in morphogenesis. Nature Reviews. Molecular Cell Biology 6 622-634.

Halbleib JM \& Nelson WJ 2006 Cadherins in development: cell adhesion, sorting, and tissue morphogenesis. Genes \& Development 20 3199-3214.

Hatta K, Takagi S, Fujisawa H \& Takeichi M 1987 Spatial and temporal expression pattern of $\mathrm{N}$-cadherin cell adhesion molecules correlated with morphogenetic processes of chicken embryos. Developmental Biology $\mathbf{1 2 0}$ 215-227.

Hertig CM, Butz S, Koch S, Eppenberger-Eberhardt M, Kemler R \& Eppenberger HM $1996 \mathrm{~N}$-cadherin in adult rat cardiomyocytes in culture. II. Spatio-temporal appearance of proteins involved in cell-cell contact and communication. Formation of two distinct $\mathrm{N}$-cadherin/catenin complexes. Journal of Cell Science 109 11-20. 
Himes AD \& Raetzman LT 2009 Premature differentiation and aberrant movement of pituitary cells lacking both Hes1 and Prop1. Developmental Biology 325 151-161.

Japon MA, Rubinstein M \& Low MJ 1994 In situ hybridization analysis of anterior pituitary hormone gene expression during fetal mouse development. Journal of Histochemistry and Cytochemistry $\mathbf{4 2}$ $1117-1125$.

Johnson KJ \& Boekelheide K 2002 Dynamic testicular adhesion junctions are immunologically unique. II. Localization of classic cadherins in rat testis. Biology of Reproduction 66 992-1000.

Johnson KJ, Patel SR \& Boekelheide K 2000 Multiple cadherin superfamily members with unique expression profiles are produced in rat testis. Endocrinology 141 675-683.

Kikuchi M, Yatabe M, Fujiwara K, Takigami S, Sakamoto A, Soji T \& Yashiro T 2006 Distinctive localization of $\mathrm{N}$ - and E-cadherins in rat anterior pituitary gland. Anatomical Record. Part A, Discoveries in Molecular, Cellular, and Evolutionary Biology 288 1183-1189.

Kikuchi M, Yatabe M, Kouki T, Fujiwara K, Takigami S, Sakamoto A \& Yashiro T 2007 Changes in E- and N-cadherin expression in developing rat adenohypophysis. Anatomical Record 290 486-490.

Korematsu K, Nishi T, Okamura A, Goto S, Morioka M, Hamada J \& Ushio Y 1998 Cadherin-8 protein expression in gray matter structures and nerve fibers of the neonatal and adult mouse brain. Neuroscience 87 303-315.

Li J, Patel VV \& Radice GL 2006 Dysregulation of cell adhesion proteins and cardiac arrhythmogenesis. Clinical Medicine and Research 4 42-52.

Luque RM \& Kineman RD 2006 Impact of obesity on the growth hormone axis: evidence for a direct inhibitory effect of hyperinsulinemia on pituitary function. Endocrinology 147 2754-2763.

Magoulas C, McGuinness L, Balthasar N, Carmignac DF, Sesay AK, Mathers KE, Christian H, Candeil L, Bonnefont X, Mollard P et al. 2000 A secreted fluorescent reporter targeted to pituitary growth hormone cells in transgenic mice. Endocrinology 141 4681-4689.

Marthiens V, Padilla F, Lambert M \& Mege RM 2002 Complementary expression and regulation of cadherins 6 and 11 during specific steps of motoneuron differentiation. Molecular and Cellular Neurosciences 20 458-475.

McElvaine AT, Korytko AI, Kilen SM, Cuttler L \& Mayo KE 2007 Pituitaryspecific expression and Pit-1 regulation of the rat growth hormonereleasing hormone receptor gene. Molecular Endocrinology 21 1969-1983.

Morel G, Gallego R, Boulanger L, Pintos E, Garcia-Caballero T \& Gaudreau P 1999 Restricted presence of the growth hormone-releasing hormone receptor to somatotropes in rat and human pituitaries. Neuroendocrinology $\mathbf{7 0}$ $128-136$.

Nagafuchi A \& Takeichi M 1989 Transmembrane control of cadherinmediated cell adhesion: a $94 \mathrm{kDa}$ protein functionally associated with a specific region of the cytoplasmic domain of E-cadherin. Cell Regulation 1 37-44.

Nakajima T, Yamaguchi H \& Takahashi K 1980 S100 protein in folliculostellate cells of the rat pituitary anterior lobe. Brain Research 191 523-531.

Noda T, Kaidzu S, Kikuchi M \& Yashiro T 2001 Topographic affinities of hormone-producing cells in the rat anterior pituitary gland. Acta Histochemica et Cytochemica 34 313-319.

Noda T, Kikuchi M, Kaidzu S \& Yashiro T 2003 Rat anterior pituitary cells in vitro can partly reconstruct in vivo topographic affinities. Anatomical Record. Part A, Discoveries in Molecular, Cellular, and Evolutionary Biology 272 548-555.

Ozawa M, Ringwald M \& Kemler R 1990 Uvomorulin-catenin complex formation is regulated by a specific domain in the cytoplasmic region of the cell adhesion molecule. PNAS 87 4246-4250.

Paez-Pereda M, Kuchenbauer F, Arzt E \& Stalla GK 2005 Regulation of pituitary hormones and cell proliferation by components of the extracellular matrix. Brazilian Journal of Medical and Biological Research 38 $1487-1494$.
Redies C, Treubert-Zimmermann U \& Luo J 2003 Cadherins as regulators for the emergence of neural nets from embryonic divisions. Journal of Physiology 97 5-15.

Robinson ICAF \& Hindmarsh PC 1999 The growth hormone secretory pattern and statural growth. In Handbook of Physiology, Section 7: The Endocrine System, Volume V: Hormonal Control of Growth, pp 329-395. New York, NY, USA: Oxford University Press.

Rubinek T, Yu R, Hadani M, Barkai G, Nass D, Melmed S \& Shimon I 2003 The cell adhesion molecules $\mathrm{N}$-cadherin and neural cell adhesion molecule regulate human growth hormone: a novel mechanism for regulating pituitary hormone secretion. Journal of Clinical Endocrinology and Metabolism 88 3724-3730.

Rukstalis JM \& Habener JF 2007 Snail2, a mediator of epithelialmesenchymal transitions, expressed in progenitor cells of the developing endocrine pancreas. Gene Expression Patterns 7 471-479.

Sasaki F \& Iwama Y 1988 Sex difference in prolactin and growth hormone cells in mouse adenohypophysis: stereological, morphometric, and immunohistochemical studies by light and electron microscopy. Endocrinology 123 905-912.

Van der Schueren B, Denef C \& Cassiman JJ 1982 Ultrastructural and functional characteristics of rat pituitary cell aggregates. Endocrinology 110 513-523.

Shimoyama Y, Takeda H, Yoshihara S, Kitajima M \& Hirohashi S 1999 Biochemical characterization and functional analysis of two type II classic cadherins, cadherin-6 and -14, and comparison with E-cadherin. Journal of Biological Chemistry 274 11987-11994.

Shirasawa N, Kihara H, Yamaguchi S \& Yoshimura F 1983 Pituitary folliculo-stellate cells immunostained with S-100 protein antiserum in postnatal, castrated and thyroidectomized rats. Cell and Tissue Research 231 235-249.

Soji T, Mabuchi Y, Kurono C \& Herbert DC 1997 Folliculo-stellate cells and intercellular communication within the rat anterior pituitary gland. Microscopy Research and Technique 39 138-149.

Suzuki SC \& Takeichi M 2008 Cadherins in neuronal morphogenesis and function. Development, Growth \& Differentiation 50 S119-S130.

Suzuki SC, Inoue T, Kimura Y, Tanaka T \& Takeichi M 1997 Neuronal circuits are subdivided by differential expression of type-II classic cadherins in postnatal mouse brains. Molecular and Cellular Neurosciences 9 433-447.

Suzuki SC, Furue H, Koga K, Jiang N, Nohmi M, Shimazaki Y, Katoh-Fukui Y, Yokoyama M, Yoshimura M \& Takeichi M 2007 Cadherin-8 is required for the first relay synapses to receive functional inputs from primary sensory afferents for cold sensation. Journal of Neuroscience $\mathbf{2 7}$ 3466-3476.

Le Tissier PR, Carmignac DF, Lilley S, Sesay AK, Phelps CJ, Houston P, Mathers K, Magoulas C, Ogden D \& Robinson IC 2005 Hypothalamic growth hormone-releasing hormone (GHRH) deficiency: targeted ablation of GHRH neurons in mice using a viral ion channel transgene. Molecular Endocrinology 19 1251-1262.

Watkins-Chow DE \& Camper SA 1998 How many homeobox genes does it take to make a pituitary gland? Trends in Genetics 14 284-290.

Zhu X, Gleiberman AS \& Rosenfeld MG 2007 Molecular physiology of pituitary development: signaling and transcriptional networks. Physiological Reviews 87 933-963.

Received in final form 28 May 2009

Accepted 2 June 2009

Made available online as an Accepted Preprint 2 June 2009 